\title{
Four European Smart City Strategies
}

\author{
Margarita Angelidou ${ }^{1}$ \\ ${ }^{1}$ Urban and Regional Innovation Research Unit, School of Engineering, Aristotle University of Thessaloniki, Greece \\ Correspondence: Margarita Angelidou, Urban and Regional Innovation Research Unit, Aristotle University of \\ Thessaloniki, P.O. Box 491, 54124 Thessaloniki, Greece.
}

Received: February 7, 2016

Accepted: February 24, 2016

Available online: March 3, 2016

doi:10.11114/ijsss.v4i4.1364

URL: http://dx.doi.org/10.11114/ijsss.v4i4.1364

\begin{abstract}
This paper provides evidence-based policy recommendations about the development of smart cities. The core characteristics of smart cities, including the use of advanced technology, human and social capital development, the development of pro-business environments and networking, are 'translated' into individual domains that characterize smart city strategies. Four major European cities (Amsterdam, Barcelona, London and Stockholm) are examined in terms of how they have so far incorporated those domains in their ongoing smart city strategies. The data are analyzed comparatively, highlighting trends and contrasting differences among strategies. The paper closes with conclusions about those characteristics and their role in smart city policy making.
\end{abstract}

Keywords: urban development; strategy; policy; sustainability; society; technology

\section{Introduction}

The technological advancements of recent decades have had not only a powerful, but also a transformative impact on urban life. The wide availability of Information and Communication Technologies (ICTs) in urban settings and their broad adoption throughout society have created a state of technological ubiquity in developed countries. As technology advances and becomes more affordable, the functionality and sustainability of urban systems undergoes significant advancements as well. At the same time, increased access to information enforces the role of knowledge as a powerful engine of economic growth. This enables the development of knowledge-based societies. Under these continuously evolving conditions, many concepts about the organization and management of the new technological capabilities have become popular, including the one of 'smart cities'.

Inspired by the above situation and the recent literature, this paper aims to illustrate the state-of-play of applied smart city strategies in large European cities and then reach conclusions about the current idea of what it means to be 'smart' in a city context. This is achieved by exploring how the core characteristics of the smart city idea have been incorporated so far in four ongoing European smart city strategies (Amsterdam Smart City, Barcelona Smart City, Smart London Plan and Stockholm Smart City).

The paper is structured accordingly. The following section (2) starts by presenting the smart city idea and pointing out the defining characteristics of smart cities, as they have been documented in the recent literature. These characteristics include (i) the central role of technology as an enabler of effective infrastructure and recourse management, (ii) the role of human and social capital as sources of knowledge dissemination and new knowledge creation, (iii) the development of pro-business environments pro-business environments attracting investment and spawning new businesses and (iv) the increasing importance of collaboration and networking of city authorities in pooling recourses, exchanging knowledge and attracting citizens and businesses. The third section of the paper (3) describes how the presented research was conducted, including the data, cases and analysis methods that were used. The fourth section (4) presents the empirical findings about each case of a smart city strategy and explores each of the previous characteristics through a critical lens, reaching conclusions about each of them individually. The last section of the paper (5) discusses the conclusions that emerge from the previous review about the smart city movement as a whole.

\section{The 'Smart city' movement and its characteristics}

\subsection{The smart city idea}

There are fundamental disagreements about the meaning and the dimensions of the smart city, while many cities claim to be 'smart' without evidence-based justification (Komninos, 2011a; Chourabi et al., 2012; Nam and Pardo, 2011a; 
Papa et al., 2013; Allwinkle and Cruickshank, 2011; Wolfram, 2012; Lombardi et al., 2012; Hollands, 2008). The discussion is ongoing, fueled by a multitude of definitions and solutions in the smart cities' arena, without a prevalent or universally acknowledged set as of yet. In this context, no city can actually claim that it has conquered smartness fully; rather, as technologies and societies are changing dynamically, the smart city is called to redefine itself and experiment with new ways of thinking about technology, and how this technology can be used to enhance common good.

Smart cities represent a conceptual development model that aspires to use ICTs for the development of a city's human, collective, and technological capital, with the ultimate scope of increasing urban sustainability. They constitute an idea for the ideal future of an urban settlement that harnesses technology. They also imply integrated processes to realize this idea. In the best case scenario, a city that aspires to become 'smart' has an integrated, forward-looking strategic plan that defines a vision and a methodology based on capitalizing digital technologies to improve urban functions and develop knowledge ecosystems. As any strategy, it is important that strategic plans for smart cities are adapted to the needs, priorities and constraints of their circumstances.

Recent estimations speak of 143 (Lee and Gong Hancock, 2012), 300-400 (Nikkei BP Cleantech Institute, 2010) and 102 smart city projects worldwide (ABI Research, 2011). It is difficult to estimate the exact number of smart city projects undergoing implementation in the different parts of the world because of abundant disagreements. Beyond doubt, however, they are popular and, for that matter, 'fashionable' in the policy arena (Lombardi et al., 2012; Kourtit and Nijkamp, 2012; Kourtit and Nijkamp, 2013). This situation complicates efforts to define the real meaning of 'smartness' in a city context and clearly distinguish a smart city's characteristics.

\subsection{Characteristics of smart cities}

As mentioned previously, the concept of the smart city emerged recently and is constantly being transformed by contemporary technological and economic trends and ongoing discussions. Nevertheless, in order to be able to study a number of applied smart city strategies comparatively, it is first essential to point out the general characteristics that define what it means to be 'smart' in an urban context. Based on these characteristics, we will proceed in the later sections of this paper to investigate how four actual smart city strategies have been designed and implemented so far.

The first distinctive characteristic of smart cities is the central role of technology as a means for accumulating, organizing and making vast amounts of information accessible to an increasing number of people, subsequently using this information to improve urban functions and save recourses. As technologies become more affordable and the urban environment gets extensively instrumented with sensors, real-time data streams and the Internet of Things (IoT) emerge. If we add to this the rising interest of people and communities to log their own data about their lives and activities, the volume of collected data becomes vast. Not only can a city's functions be monitored constantly, but also, with the help of advanced analytics, they can be audited to identify prevailing patterns and trends, predict incidents before they even occur and adjust the provision of services and goods depending on the circumstances. Public authorities can make better-informed and documented decisions and solve problems successfully, while the city's populace can access efficient and high-end services in the domains of economic activity, governance, quality of life and utility management (Komninos, 2011a; Komninos, 2011b; Schaffers et al., 2011). This technologically-enabled ecosystem yields improvements of a city's functions, enhancing environmental sustainability and rendering the city 'smart' (Allwinkle and Cruickshank, 2011; Caragliu et al., 2009; Tranos and Gertner, 2012; Angelidou, 2014).

The second quality of smart cities is the advancement of human and social capital through knowledge creation and dissemination, advanced participation and digital inclusion, and the establishment of new forms of innovation (open, social). In smart cities, a large fraction of the available knowledge is produced collectively; knowledge is an asset that stems from everybody's contribution. Smart cities attract highly qualified people and a skilled labor force because of their openness and their eagerness to use technology in effective and innovative ways. They attract creative people who build creative cultures and industries, which in turn foster the development of knowledge ecosystems that bring prosperity to the city. In addition, it is now well documented that creative, intelligent and highly skilled people are the most powerful engines of urban development (Edvinsson, 2006; Glaeser and Berry, 2006; Shapiro, 2006; Florida, 2002; 2005; Landry, 2000); they produce new ideas, products and strategies, either individually, or in collaboration within social networks (Komninos, 2009). The 'crowd' can be smart; collective intelligence is more powerful than any machine or individual intelligence (Ratti and Townsend, 2011). In parallel, smart city programs provide platforms for engaging citizens and stakeholders and assessing the viability of smart city solutions and services in real-life contexts (Carter et al., 2011; Bria, 2012; González and Rossi, 2012). Overall, the city benefits widely from localized knowledge spillovers, collective intelligence functions and the development of inclusive communities that confront the challenges and grasp the opportunities of the rising digital economy (Allwinkle and Cruickshank, 2011; Caragliu et al., 2009; Tranos and Gertner, 2012; Hollands, 2008; Angelidou et al., 2012; Angelidou, 2014).

The smart city movement is also geared towards the advancement of the business sector, to be realized through a high 
record of entrepreneurial agility, investment attraction and new business creation. Smart cities, as documented in the recent bibliography, are characterised by a distinctive emphasis on business-led urban development and attraction of capital. They aim to forge business-friendly environments offering advanced services to businesses and entrepreneurs. They also claim to nurture the development of highly professional entrepreneurial environments, providing the ideal preconditions for businesses to prosper, innovate and network (Caragliu et al., 2009; Hollands, 2008; Tranos and Gertner, 2012). Furthermore, in the EU's current policy framework, RIS3 strategies for smart specialization call, among others, entrepreneurial actors to explore opportunities in existing or new sectors and experiment with new activities, to pin-point the most promising areas for future regional development (Foray et al., 2012). On the whole, both European policies and the smart city movement place a distinct priority in advancing and diversifying the entrepreneurial environments of cities.

Finally, critical thinking about smart cities emphasizes networking within and among cities and regions, for purposes of image making, best practice dissemination, production base diversification and the establishment of economies of scale. In today's knowledge economy and culture, city authorities find themselves increasingly under pressure to offer more innovative and high quality services, while increasing public endorsement. Cities are geared towards creating alliances and collaboration networks to exchange knowledge and coordinate recourses, while bringing out the diversity and unique character of their locus; most cities already have such alliances in place. Marketing and communication techniques have penetrated strategies for future urban development, including smart cities. Authorities attempt to communicate their smart city plans to the public by sharing concepts (promotional identity and brand), visions, goals, priorities, and even strategic plans (Nam and Pardo, 2011b) and by publishing annual reports, including performance data and statistics (Bélissent, 2011). Networking is today realized primarily thought online digital media (websites, social media, wikis etc.) and in a European context, through trans-regional and trans-national collaboration, especially in the field of smart cities.

\section{Research Design}

This section describes how the research presented in this paper was designed, including the data, cases and analysis method that were used and why they were chosen.

\subsection{Data Selection and Accumulation}

First was decided the information that would be collected about smart city strategies. Taking into account the framework of the available literature, the characteristics of smart cities (section 2.2.) were 'translated' into domains to be surveyed in each case. The followings show these characteristics and their breakdown:

Characteristic 1: Central role of technology

- Domain 1: Smart technologies and infrastructure: how each smart city strategy approaches technology and infrastructure

- Domain 2: Digital services and applications: the types of services and applications offered in the context of a smart city strategy. These can be categorized in the domains of: (i) Economic activity: manufacturing, commerce, businesses and finance, education, research, health, tourism, primary sector, (ii) City Infrastructure \& Utilities: transport, energy, water, waste, (iii) Quality of Life: social inclusion, social care, safety and security, environmental alert and (iv) City Governance: city hall services, citizen participation, informed top-level decision-making, monitoring and benchmarking (Komninos, 2011a).

Characteristic 2: Human and social capital advancement

- Domain 1: Education and training: smart city strategies that promote infrastructures, institutions, and programs for high quality and innovative undergraduate/ postgraduate/ vocational education.

- Domain 2: Social \& Digital Inclusion: the main drive behind the smart city strategy: Social inclusion, addressing the digital divide, accessibility, closing of skills gap, etc.

- Domain 3: Bottom-up approach: in the context of the smart city, a bottom-up approach refers to the involvement of the city's people, interest groups and organizations (i.e. 'stakeholders') in all or some stages of the smart city development. With engagement, users with different knowledge domains and levels, skills, experiences, roles, points of view and needs contribute to the success of the smart city.

- Domain 4: Experimentation and testing of new products and solutions: pilot programs and test beds are platforms that are used to assess the viability of specific solutions and services or to engage citizens and stakeholders. They are useful in delivering proof of concept, testing specific tools and techniques and validating and perfecting the proposed strategic framework.

- Domain 5: Culture shift: smart city strategies driving a culture shift throughout society, for example, towards 
environmental awareness, a technology savvy society, a participatory society, creative and innovative thinking, etc.

Characteristic 3: Business sector advancement

- Domain 1: Measures for Business sector development: these include measures for attracting and developing innovative businesses and knowledge workers: (i) financial incentives (tax exemptions, bank loans with privileged interest rates, business angels, seed funding, venture capital etc.) (ii) business incubation services (growth assistance for startup and early-stage companies) and (iii) technology transfer and commercialization services (intellectual property protection, industrial support of ongoing Research and Development (R\&D), collaboration platforms with academia, industry and government).

Characteristic 4: Networking

- Domain 1: Partnerships and alliances: Partnership with other cities for knowledge and experience exchange, in order to disseminate best practices, develop complementarities in weak and strong points, coordinate recourses and create economies of scale.

- Domain 2: Marketing: A dedicated strategy about how the smart city organization will create, deliver and communicate the value of the project to the wider audience, so as to gain broader support and acceptance. This may include promotional events to market the smart city project, participation in conferences/competitions/awards, a branding strategy, etc.

- Domain 3: Digital presence (website, social media): A website to make the smart city project known to a broader audience and provide information for stakeholders. Presence on common social media (city-operated blog, Facebook, Flickr, FourSquare, Google+, Instagram, LinkedIn, Pinterest, Tumblr, Twitter, YouTube, Vimeo).

\subsection{Case selection}

Four major European cities that are in the process of developing or implementing a smart city strategy were selected to be studied: Amsterdam, Barcelona, London and Stockholm. Their selection took place considering the following criteria:

- $\quad$ Conformation with the working definition of the 'smart city' (section 2.1)

- The existence of an integrated smart city strategy, to the extent possible

- The degree of data availability

The data was sourced through academic articles published in scientific journals and conferences, academic and corporate research reports, government documents, corporate documents and non-scientific articles published during the period January 2014- September 2014 on online sources (technology websites, online newspapers and blogs, etc.)

\subsection{Case selection}

The analysis method that was used is the Multiple case study analysis ${ }^{1}$ (Miles et al., 2013; Yin, 2003; Eisenhardt, 1989), is a type of qualitative analysis that presents and compares the main findings of qualitative research in a detailed and systematic way. In order to perform the multiple case study analysis, cross-case matrices were developed (presented in the Appendix 1 of this paper). These matrices allow comparison of findings systematically across cases and analyze similarities, differences and patterns of behavior.

\section{Results}

\subsection{Empirical Findings}

The first smart city strategy that was studied is Amsterdam, the Netherlands. Amsterdam Smart City is being realized through a partnership among businesses, authorities, research institutions, and the people of Amsterdam (over 70 partners, including CISCO and IBM). The aim of this partnership is the transformation of the Amsterdam metropolitan area into a smart city with the ultimate goal of reducing CO2 emissions. Amsterdam's smart city platform connects all of the city's stakeholders through 'smart' collaborations; it brings them together with the purpose of developing and implementing shared ideas and solutions for the city. Currently the program comprises 32 projects that present innovative ideas and new business models across Amsterdam's neighborhoods. These projects fall within seven 'areas of interest': Smart Mobility, Smart Living, Smart Society, Smart Areas, Smart Economy, Big \& Open Data and Infrastructure (water, roads, energy, ICT). Initially, they are to be tested on a small scale and the ones that prove to be effective will be extended to larger areas. All projects are built around informing citizens, entrepreneurs and the public sector about their energy consumption and educating them about how to manage it more prudently. To achieve this,

\footnotetext{
${ }^{1}$ also known as ' cross-case analysis'
} 
smart devices and wireless meters transmit information over broadband networks helping the citizens and organizations of the city to behave more 'intelligently' by reducing their energy consumption. Two well-known projects of Amsterdam Smart City are the 'Climate Street' and the 'West Orange' project. They are a commercial and a residential area respectively, where smart and energy-saving technologies were introduced along with smart meters and energy displays with the purpose of encouraging users to save energy and reduce their carbon footprint (Amsterdam Smart City official website, 2014; Baron, 2012; Štáhlavský, 2011; Sauer, 2012).

The next strategy was the one for the Smart City of Barcelona, Spain. The City of Barcelona has been using ICTs to improve urban functions for more than a decade now, with dispersed projects running in various departments. Barcelona also has a long experience in Living Lab initiatives and is in the process of developing a formal smart city strategy. The Urban Habitat Department (the so called 'Smart City' department) was created after a major organizational reform. It is a new umbrella structure to coordinate services previously provisioned by individual City Departments regarding infrastructure, ICTs, urban services, urban planning, environment, housing, architecture, energy and water, etc. Under this new organizational scheme, previously isolated government departments are called to coordinate their strategy in order to achieve common goals. In addition, the formal strategy has a global outlook, seeking to forge an open environment for the collaboration among government, industry, academia and citizens. It comprises three individual axes: 'international promotion', 'international collaboration' and 'local projects'. The number of local projects is over 100 -some examples include the New Municipal Network, Energy Efficiency in Buildings, Smart Lighting, Smart Water, Smart Transportation, Smart Citizens, O-Government \& Efficiency and Optimized Waste Collection (Barcelona Smart City official website, 2014; Ajuntament de Barcelona, 2013; Ajuntament de Barcelona, 2012; Bakici et al., 2012).

The next smart city strategy studied is London's 'Smart London Plan'. In London, the first concerted effort to use smart city applications took place in 2012, with the purpose of managing public transport under the demanding circumstances of that year's Olympic Games. Eventually, in 2013, the Smart London Board was created, comprising academics, businesses and entrepreneurs, commissioned to advise the Greater London Authority on smart city matters. The Board produced the Smart London Plan, organized around seven key themes: (1) placing Londoners at the core of innovation, (2) providing access to open data, (3) leveraging London's research technology and creative talent, (4) facilitating networking among and with other smart city stakeholders (5) enabling 'smarter' infrastructure development and management (6) providing more effective and integrated City Hall services and (7) offering a 'smarter' London experience for all. The plan includes a series of actions and measures of success for each key theme. London's smart city strategy is mostly focused around the institutional and digital space, rather than the physical. However, it also includes some improvements and new developments in infrastructure, as well as urban regeneration projects. The most important one is 'Here East', a 1,200,000 sq. ft. digital quarter to be developed at Queen Elizabeth Olympic Park, leveraging the buildings of the former Press and Broadcast Centers of the 2012 Olympics. It will be a campus that supports growth of London's technology sector, combining business, technology, media, education and data to create a local system of innovation. As such, it will provide space for start-ups, education and post-graduate research (Greater London Authority official website, 2013; Fletcher-Smith, 2014; Malthouse, 2014).

In the case of Stockholm Smart City, Sweden, the data collection process has already been completed. Stockholm has a long tradition in research and innovation in environmental and information technology. It also has a well-established culture as a livable and sustainable city that offers high living standards and efficient government services. Stokab is the name of the city-owned company which has been developing and managing the city's open fiber-optic communications network and promoting optimal conditions for ICT development since 1994. Today Stokab offers $100 \%$ broadband coverage within the Stockholm region. In Stockholm's smart city strategy, environmental and information technologies are tested and used extensively throughout the city's infrastructure, with the purpose of creating a flourishing ecosystem that involves the city's inhabitants, the private industry and the public sector, while fostering a dynamic local economy. The strategy is citizen-centric, focusing on providing enhanced e-government services to citizens. Government services include online City Hall services and services for mobility and energy improvement based on real-time data collection about traffic and weather. The data are collected through Global Positioning Systems (GPS) placed on public vehicles, as well as traffic and weather sensors, pollution monitoring equipment, etc. Residents have real-time information about traffic flow, journey times, and best travel options, including a journey planner. The City is also using pilot projects to test technology solutions but in a different light than most of its counterpart smart cities: it uses large scale, real environment test beds, called 'demonstrators'. One of those demonstrators, for example, is 'Kista Science City', Sweden's world-class ICT cluster, where Research and Development (R\&D) and technology transfer take place between businesses and the academia, demonstrating an exemplary concentration of expertise, innovation and business opportunities in the ICT field. Another demonstrator is the 'Royal Seaport' area, which is being redeveloped into a 'smart' area with a capacity of 20,000 residents and 50,000 workers, to be used for testing innovative technologies and services in health care, energy and transport (Stockholm smart city official website, 2014; Johnson, 2014; Stockholm 
Royal Seaport Innovation official website, 2014; The Intelligent Community Forum, 2009).

\subsection{Multiple case study analysis results}

The previous smart city strategies were screened to acquire information about each smart city characteristic (section 2.2.) and its constituent Domains (section 3.1.). This information was studied comparatively regarding each characteristic across the four cases. The results are presented in the following paragraphs.

In terms of technology as a core component of smart city strategies, all four cities invest predominantly in broadband networking (mostly wireless and optical fiber) and on a second level on sensor networking (sensors on stationary and mobile devices). Wireless broadband networking is obviously a more convenient option for cities with complex physical structures already in place. However, Stockholm's case of $100 \%$ optical fiber coverage is an exemplar that is the result of proactive policy making and continuous efforts by the City. In terms of digital services and applications, the foremost frequency is observed in the domain of city infrastructure and utilities, namely energy, transport and waste management. Government services play an important role, too, encompassing city hall services and means for engaging citizens in the policy making process. Digital services for the improvement of economic activity and quality of life have a non-existent or secondary role in the studied smart city strategies, although one would expect the contrary regarding cities with a long history, culture and established social innovation dynamics. This phenomenon can be explained by the fact that the current experience, availability and technological maturity of digital services in the domains of city infrastructure and utilities and government services far outweigh the more 'sensitive', vaguely defined and largely untried services in the domains of economic activity and quality of life. The following cross case matrix (Table 1) summarizes the characteristics of each case:

Table 1. Cross case matrix displaying the status of each case with regard to Characteristic 1: Central role of technology (source: author's elaboration)

\begin{tabular}{|c|c|c|}
\hline City & Domain & ation \\
\hline \multirow{2}{*}{ 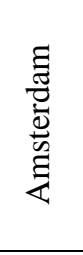 } & $\begin{array}{l}\text { Smart technologies } \\
\text { and infrastructure }\end{array}$ & $\begin{array}{l}\text { Broadband and sensor networking. Innovative technologies for energy } \\
\text { consumption monitoring and renewable energy production. }\end{array}$ \\
\hline & $\begin{array}{l}\text { Digital services and } \\
\text { applications }\end{array}$ & $\begin{array}{l}\text { Services and applications for energy consumption monitoring and renewable } \\
\text { energy production (distributed power generation, energy advice, energy displays, } \\
\text { energy storage, smart meters, smart lighting, electric vehicles, EV charge points, } \\
\text { electric waste collection, sustainable logistics and ultra-fast charging). }\end{array}$ \\
\hline \multirow{2}{*}{ 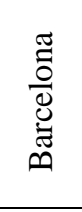 } & $\begin{array}{l}\text { Smart technologies } \\
\text { and infrastructure }\end{array}$ & $\begin{array}{l}\text { Broadband and sensor networking. Emphasis on connectivity as a means for better } \\
\text { urban services, public participation, mobility and sustainability. }\end{array}$ \\
\hline & $\begin{array}{l}\text { Digital services and } \\
\text { applications }\end{array}$ & $\begin{array}{l}\text { Services and applications for (i) transport, energy efficiency in buildings and } \\
\text { utilities, waste collection etc., (ii) government services and citizen participation, } \\
\text { (iii) urban resilience. }\end{array}$ \\
\hline \multirow[b]{2}{*}{ 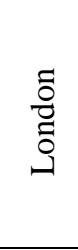 } & $\begin{array}{l}\text { Smart tech } \\
\text { and infrastr }\end{array}$ & roadband and sensor networking. \\
\hline & $\begin{array}{l}\text { Digital services and } \\
\text { applications }\end{array}$ & $\begin{array}{l}\text { Services and applications for (i) infrastructure management (smart grid, smart } \\
\text { waste collection, 3D visualizations of infrastructure and smart transport for people } \\
\text { and freight), (ii) city governance (e.g. 'Talk London' platform), joint working } \\
\text { across different policy and physical areas, city planning and city management. }\end{array}$ \\
\hline \multirow{2}{*}{ 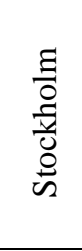 } & $\begin{array}{l}\text { Smart technologies } \\
\text { and infrastructure }\end{array}$ & $\begin{array}{l}\text { Mostly broadband networking (through Stockab, the city-owned company that } \\
\text { manages the city's open fiber-optic communications network of a } 100 \% \text { broadband } \\
\text { coverage). }\end{array}$ \\
\hline & $\begin{array}{l}\text { Digital services and } \\
\text { applications }\end{array}$ & $\begin{array}{l}\text { Services and applications for (i) mobility and energy consumption improvement } \\
\text { based on real-time data collection about traffic and weather and (ii) government } \\
\text { services (online council meeting, permits, applications). }\end{array}$ \\
\hline
\end{tabular}

In terms of human and social capital advancement, and specifically education and training towards 'smart' people and economy, the situation appears to be fragmented. Most smart city programs include minimal education and training activities for individuals, mostly confined to the use of selected 'smart' devices rather than extending the population's digital skills over the broad spectrum of smart city capabilities and closing the skills gap. The exemplar here is London's smart city strategy, which targets education and training in multiple levels, including physical and digital educational infrastructure, institutions and targeted programs. Educational institutions have an active role within the smart city ecosystem, as they are expected to become hubs of innovation in education, collaborative research in edge sectors and multifaceted social interaction. However, a weak link is documented between academia and industry as well as government, meaning that new knowledge and innovative ideas face difficulties in circulating, becoming 
commercialized and adopted throughout society.

Social and digital inclusion appears as the most problematic policy area. All strategies regard social and digital inclusion as related loosely or even completely disconnected with the smart city idea. No mention whatsoever to these aspects was found in two of the studied smart city strategies (Amsterdam, Stockholm), while one strategy includes it as priority but does not elaborate the idea further (Barcelona), and another one (London) regards the issue of social and digital inclusion as a parallel, standalone policy area.

Bottom up approaches, on the other hand, seem to be a smart city domain where experience is starting to bear fruits. The studied smart city strategies demonstrate an increased understanding of the significance of participatory procedures, as well as their underlying technological and cognitive processes, which are increasingly becoming common ground in public policy making. They foresee the collaboration among the cities' inhabitants, businesses and public sector as a source of new and effective knowledge production and as a precursor for the development of open knowledge and innovation ecosystems. However, there is still work to be done towards extending bottom-up engagement into the strategy development phase (besides the implementation phase). In the studied cases, the most important vehicles for bottom-up engagement are primarily Open Data initiatives and, secondarily, Living Labs. Nevertheless, there is still progress to be made, and as technological advancements enable new forms of collaboration and bottom-up organization, this domain will not cease to require special attention.

In addition, we observe that testing of smart city solutions is an integral part of smart city strategies. Pilot projects are useful in delivering proof of concept, testing specific tools and techniques and validating and perfecting solutions and strategic frameworks. However, the scale and the degree of dispersion behind the testing of those solutions vary. In Amsterdam and Barcelona most pilot programs test a specific technology on a neighborhood scale -for example, pilot energy management systems along commercial streets or residential neighborhoods. Other pilot programs in the same cities extend over multiple points throughout the city -for example electrical vehicle transport systems including dispersed electric vehicle and charging stations. London's strategy includes reasonably fewer and locally concentrated piloting activities, focusing on so-called 'lighthouse' projects that demonstrate new approaches. Finally, in Stockholm, a completely different approach is adopted, prioritizing integrated, large scale test beds, called 'demonstrators'. These demonstrators forge new, real environments where many smart city services and solutions are tested at the same time; for example, the Royal Seaport area, with a capacity of 20.000 residents and 50.000 workers, is conceived as one of these demonstrators; Kista Science City is also classified as a demonstrator. In Stockholm, the thought is that this type of large-scale demonstrator allows a better understanding of the potential impact of smart city projects.

Inducing a culture shift throughout society is the domain that summarizes the long term effect of all the above domains and their procedures. The foremost objective in this direction is the establishment of a climate of 'openness', dialogue and collaboration among the city's inhabitants. Other objectives include the development of tech-savvy and environmentally aware people and communities. The following cross case matrix (Table 2) summarizes the characteristics of each case:

Table 2. Cross case matrix displaying the status of each case with regard to Characteristic 2: Human and social capital advancement (source: author's elaboration)

\begin{tabular}{|c|c|c|}
\hline City & Domain & Data / Information \\
\hline \multirow{5}{*}{ 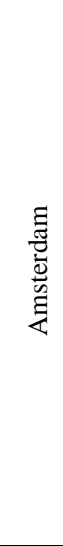 } & Education and training & $\begin{array}{l}\text { No large scale or integrated education and training activities. Some training to facilitate the } \\
\text { implementation of the initiatives, for ex. how to monitor energy consumption devices and how to use } \\
\text { open data. }\end{array}$ \\
\hline & $\begin{array}{l}\text { Social \& Digital } \\
\text { Inclusion }\end{array}$ & No information. \\
\hline & Bottom-up approach & $\begin{array}{l}\text { Collaboration among the city's stakeholders, including its people and knowledge institutions to } \\
\text { develop knowledge and innovation ecosystems. Both in strategy development and strategy } \\
\text { implementation. Open data and Living Lab initiatives. }\end{array}$ \\
\hline & Experimentation & $\begin{array}{l}\text { City seen as platform for testing innovative ideas and solutions. Projects, ideas and business models } \\
\text { are initially tested on a small scale and the ones that prove to be effective will be extended to include } \\
\text { other areas. }\end{array}$ \\
\hline & Culture shift & $\begin{array}{l}\text { Towards sensible energy consumption and sustainable ways of living. Towards a climate of openness } \\
\text { and exchange of innovative ideas. }\end{array}$ \\
\hline \multirow{2}{*}{ 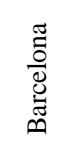 } & Education and training & $\begin{array}{l}\text { Universities are invited to collaborate with research centers and businesses to formulate 'smart ' } \\
\text { clusters. }\end{array}$ \\
\hline & $\begin{array}{l}\text { Social \& Digital } \\
\text { Inclusion }\end{array}$ & $\begin{array}{l}\text { Social cohesion and accessibility are stated as primary goals. It is not obvious, however, how this will } \\
\text { be achieved through the foreseen smart city programs. }\end{array}$ \\
\hline
\end{tabular}




\begin{tabular}{|c|c|c|}
\hline & Bottom-up approach & $\begin{array}{l}\text { The city's ingenuity, innovation and talent (entrepreneurs, businesses, universities, institutions etc.) } \\
\text { are expected to contribute to making Barcelona more innovative. Mostly in strategy implementation } \\
\text { and less in strategy development. Open data and Living Lab initiatives. }\end{array}$ \\
\hline & Experimentation & $\begin{array}{l}\text { Aim to establish the City as an international benchmark platform for innovative solutions. The } \\
22 @ \text { Urban Lab encompasses } 14 \text { pilot programs and aims to use the city as a laboratory of new } \\
\text { solutions for marketing municipal services, and also for companies to use as a space for testing, } \\
\text { facilitating market access and promoting competitiveness. }\end{array}$ \\
\hline & Culture shift & Towards a climate of cooperation, openness and flexibility. \\
\hline \multirow{5}{*}{ 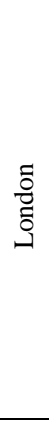 } & Education and training & $\begin{array}{l}\text { Education for developing digital technology (not just consuming it). Increase of computer science } \\
\text { uptake in London's schools. Program for training of young people with tech city firms. 'Tech City } \\
\text { Institute' will provide a space for the discussion of the role that technology can play in the city's } \\
\text { development. }\end{array}$ \\
\hline & $\begin{array}{l}\text { Social \& Digital } \\
\text { Inclusion }\end{array}$ & Pan-London digital inclusion strategy about how to address digital exclusion. \\
\hline & Bottom-up approach & $\begin{array}{l}\text { Bottom-up engagement is a focal point of the strategy. The city's people, businesses and other } \\
\text { stakeholders are seen as indispensable sources of innovation. Open data initiative. }\end{array}$ \\
\hline & Experimentation & Small number of project-based pilots. 'Lighthouse' projects to demonstrate new approaches at scale. \\
\hline & Culture shift & Towards a climate of cooperation among the city's stakeholders. \\
\hline \multirow{5}{*}{$\begin{array}{l}\frac{\Xi}{0} \\
\frac{\pi}{\frac{\pi}{0}} \\
\frac{0}{0}\end{array}$} & Education and training & $\begin{array}{l}\text { The City offers e-learning packages on issues such as environmental-friendly practices and Green IT } \\
\text { to the City's employees, students and companies. The city's universities and research centers have an } \\
\text { active role in the smart city strategy providing educational programs and engaging in R\&D in related } \\
\text { fields. }\end{array}$ \\
\hline & $\begin{array}{l}\text { Social \& Digital } \\
\text { Inclusion }\end{array}$ & No information. \\
\hline & Bottom-up approach & $\begin{array}{l}\text { The city's inhabitants, private industry and public sector are called to collaborate to produce } \\
\text { knowledge collectively. Open data initiative. }\end{array}$ \\
\hline & Experimentation & $\begin{array}{l}\text { City open to using pilots to test technology solutions, through large scale, real environment test beds, } \\
\text { called "demonstrators" (e.g. 'Kista Science City' and 'Royal Seaport' area). }\end{array}$ \\
\hline & Culture shift & $\begin{array}{l}\text { Towards a climate of tech-savvy people and communities. Locals are well trained and early adopters } \\
\text { of new technology. }\end{array}$ \\
\hline
\end{tabular}

Proceeding to the third characteristic, all of the four strategies include measures to help their business sector to develop, but each prioritizes different aspects. The most prominent measure regards technology transfer and commercialization, focusing on facilitating business networking and collaboration with academia and citizens. Financial support for business growth follows, involving mostly venture and seed capital funding. Incubation services for early-stage businesses are also frequent, although somewhat less commonly adopted. The above observations could be explained by the fact that technology transfer and commercialization stand for capabilities of high added value in innovative businesses; at the same time, this domain is advancing rapidly thanks to recent technological developments, with the number of related platforms increasing. On the other hand, nowadays, there is a lot of experience available in business incubation, while to a large extent it is an affair of the private sector, i.e. it is exercised by private business incubators which are not formally included in smart city strategies. Overall, one can discern a neoliberal approach towards business sector development, with businesses expected to determine their own position within the broadband economy, leverage offered infrastructures to their best interest, and grasp opportunities in a laissez-faire atmosphere for economic development. The following cross case matrix (Table 3) summarizes the characteristics of each case:

Table 3. Cross case matrix displaying the status of each case with regard to Characteristic 3: Business sector advancement (source: author's elaboration)

\begin{tabular}{lll}
\hline City & Domain & Data / Information \\
\hline 焉 & Measures for Business & Seed funding programs / collaborations with banks. Incubation services. Support in international \\
networking of local technology companies and startups.
\end{tabular}




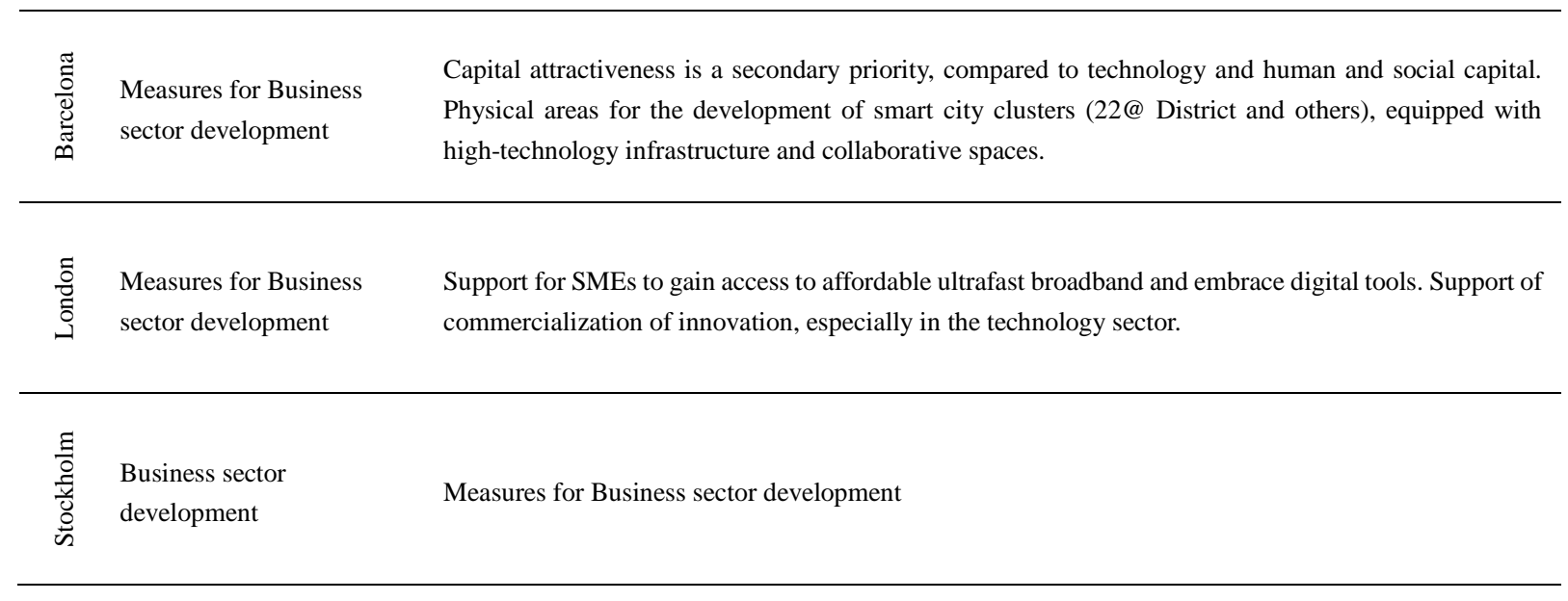

Finally, although smart cities harness digital technology for human and social capital advancement, the overall situation in terms of networking has not met its target. It is encouraging that all of the cities participate in networks to exchange knowledge and software, find out about best practices, promote their brand and attract investors and other collaborators in the venture towards 'smartness'. When it comes to marketing, though, none of them has developed an integrated marketing strategy. Marketing efforts are limited to occasional participation in international and promotional events. Barcelona's smart city strategy is the only case with an explicit mission to promote the project internationally, although it is not clearly described how this will be achieved besides the occasional participation/hosting of international events. The scarce digital presence of the studied smart city strategies is even more alarming; the only one with an integrated and long-standing website is Amsterdam, while Barcelona's website about the smart city project was inaugurated only recently. The smart city of London and Stockholm, on the other hand, are being promoted through sections in government websites which, unfortunately, provide limited information about the projects. In terms of social media presence, the only well-performing one is Amsterdam, demonstrating a frequent activity on multiple social media channels. The following cross case matrix (Table 4) summarizes the characteristics of each case:

Table 4. Cross case matrix displaying the status of each case with regard to Characteristic 1: Central role of technology (source: author's elaboration)

\begin{tabular}{|c|c|c|}
\hline City & Domain & Data / Information \\
\hline \multirow{3}{*}{ 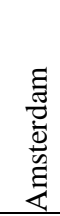 } & $\begin{array}{l}\text { Partnerships and } \\
\text { alliances }\end{array}$ & Alliances with other cities for knowledge exchange. \\
\hline & Marketing & $\begin{array}{l}\text { Organized efforts started in summer 2014. Amsterdam Connects' program, to promote the } \\
\text { developed solutions to the international market. Brand name. }\end{array}$ \\
\hline & Digital presence & Website: standalone. Social media: Facebook, Google+, LinkedIn, Twitter, YouTube. \\
\hline \multirow{3}{*}{ 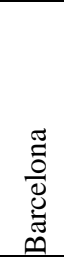 } & $\begin{array}{l}\text { Partnerships and } \\
\text { alliances }\end{array}$ & $\begin{array}{l}\text { Participation in the City Protocol Society, collaboration with other cities and research } \\
\text { centers. }\end{array}$ \\
\hline & Marketing & $\begin{array}{l}\text { No integrated marketing strategy. Priority to international promotion: participation in } \\
\text { international events, multinational corporate events and international lobbies. Brand name. }\end{array}$ \\
\hline & Digital presence & $\begin{array}{l}\text { Website: standalone. Social media: no. Info about smart city project is communicated via the } \\
\text { City's social media channels. }\end{array}$ \\
\hline \multirow[b]{3}{*}{ 苂 } & $\begin{array}{l}\text { Partnerships and } \\
\text { alliances }\end{array}$ & $\begin{array}{l}\text { Collaboration with other cities with other cities for knowledge exchange. Some dedicated } \\
\text { events. }\end{array}$ \\
\hline & Marketing & No integrated marketing strategy. No brand name. \\
\hline & Digital presence & $\begin{array}{l}\text { Website: section on the website of the Greater London Authority. Social media: no. Info } \\
\text { about smart city project is communicated via the City's social media channels. }\end{array}$ \\
\hline \multirow{3}{*}{ 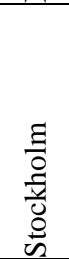 } & $\begin{array}{l}\text { Partnerships and } \\
\text { alliances }\end{array}$ & $\begin{array}{l}\text { Rather limited collaboration and networking activities. Some dedicated events that have to } \\
\text { do with specific initiatives, such as Open Data. Awards: 'Green Capital of Europe' (2009), } \\
\text { 'Intelligent Community of the Year' (2009). }\end{array}$ \\
\hline & Marketing & No integrated marketing strategy. No brand name. \\
\hline & Digital presence & $\begin{array}{l}\text { Website: section of City's website. Social media: no. Info about smart city project is } \\
\text { communicated via the City's social media channels. }\end{array}$ \\
\hline
\end{tabular}




\section{Conclusion}

Apparently, many cities fail to see smart city programs as part of their long-term, comprehensive development plan and, consequently, they do not engage in methodical strategic planning. However, smart city strategies represent very important urban development policies that include large investments and long-lasting physical infrastructures. They yield serious consequences in the delivery of services and the relationship among the public sector, citizens and businesses, shaping the future of society and governance in the years to come. It is thus essential to study them methodically and strategically, including all stages of strategy development and capitalizing broadly on of the city's resources.

Undeniably, the defining characteristic of a smart city strategy is the promotion of technological infrastructure development. Technology and artificial intelligence are indispensable dimensions of a smart city. It seems that cities opt for tried-out and quick result yielding technological solutions in a variety of domains, with a preference on transport, energy and waste management. Nevertheless, technology is not an end in itself. Smart city strategies should combine tested and leading edge technology, rather than focusing on either; the first one secures efficient function and broad adoption, while the second one promotes new and innovative solutions. Experimenting with new technologies and solutions is an integral element of smart city strategies, and it can take place to various extents ranging from a city block to whole neighborhoods or the entire city.

Technology would be useless if it didn't promote the development of human and social capital. Strategic planning for the development of smart cities needs to capitalize on both technological advancement (i.e. digital intelligence) and on the development of knowledge and innovation networks (i.e. human intelligence); technology underpins the development of knowledge and vice-versa, improving knowledge dissemination, social innovation and digital inclusion. Most smart city strategies seek to improve human and social capital by (a) developing their 'soft' infrastructure, namely social and education programs to improve accessibility, inclusion, and awareness of the public and/or (b) developing their 'hard' infrastructure in form of educational and social facilities. There is also a trend to establish dedicated areas within smart cites, where academia and industry collaborate and engage in innovative activities that overall contribute positively to the development of human and social capital.

Smart city strategies seek to enhance the attraction capital predominantly by offering financial and operational incentives (government services for businesses, business incubation services, and incentives such as tax exemptions and favorable financing schemes) and collaboration opportunities with other businesses, the government and academia. Some smart city strategies also offer showcase opportunities (businesses have the opportunity to demonstrate their products and services in real-life settings) and business promotion services (platforms to market the city's businesses). Nonetheless, attracting capital and investments are important elements of smart city strategies.

Collaboration and networking, referring to partnerships with other cities for knowledge and experience exchange and examining complementarities in strengths and weaknesses, is a basic horizontal characteristic of smart cities, too. Large and established cities, such as the ones studied in this paper, are in privileged position, as they are already experienced in international networking and are members of various networks and city alliances that they can leverage. Special attention should be paid to promote the digital presence of the city (website, social media). Such promotion will underpin efforts towards becoming smart and engaging stakeholders in this process.

Overall, it seems that we are finally heading towards a true integration of the digital with physical and institutional dimensions of the smart city. Physical planning and social policy, then, can and should underpin the digital or 'smart' dimension of the city and promote its integration upon them.

\section{References}

ABI Research. (2011). \$39.5 Billion Will Be Spent on Smart City Technologies in 2016. Retrieved from http://www.abiresearch.com/press/3768.

Ajuntament de Barcelona. (2012). Barcelona Smart City Tour. http://www.slideshare.net/barcelonactiva/barcelona-smart-city-tour-15080538

Ajuntament de Barcelona. (2013). Barcelona Smart City; The vision, focus and projects of the City of Barcelona in the context of Smart Cities. http://www.slideshare.net/MicrosoftSuomi/city-next-smartbarcelona-28102013

Allwinkle, S., \& Cruickshank P. (2011). Creating Smart-er Cities: An Overview. Journal of Urban Technology, 18(2), 1-16. http://dx.doi.org/10.1080/10630732.2011.601103

Amsterdam Smart City official website. (2014). Amsterdam Smart City. http://amsterdamsmartcity.com/about-asc.

Angelidou, M. (2014). Smart city policies: A spatial approach. Cities, 41(Supplement), S3-S11. http://dx.doi.org/10.1016/j.cities.2014.06.007 
Angelidou, M., Gountaras, N., \& Tarani, P. (2012). Engaging Digital Services for the creation of urban Knowledge Ecosystems: The case of Thermi, Greece. International Journal of Knowledge-Based Development, 3(4), http://dx.doi.org/331-350. 10.1504/IJKBD.2012.050090

Bakici, T., Almirall, E., \& Wareham, J. (2012). A Smart City Initiative: the Case of Barcelona. Journal of the knowledge economy, 4(2), 135-148. http://dx.doi.org/10.1007/s13132-012-0084-9

Barcelona Smart City official website. (2014). BCN Smart City. Retrieved from: http://smartcity.bcn.cat/en/.

Baron, G. (2012). Amsterdam Smart City.

http://www.unece.org/fileadmin/DAM/hlm/prgm/hmm/green_economy/Nov_27_2012/presentations/1_Ger_Baron _smart_Amsterdam.pdf.

Bélissent, J. (2011). Smart City Leaders Need Better Governance Tools. Forrester. Retrieved from: http://forrester.grnet.gr/Smart+City+Leaders+Need+Better+Governance+Tools/quickscan/-/E-RES58966\#/Smart+ City+Leaders+Need+Better+Governance+Tools/quickscan/-/E-RES58966

Bria, F. (2012). New governance models towards an open Internet ecosystem for smart connected European cities and regions. Open Innovation 2012, Directorate-General for the Information Society and Media, European Commission: 62-71.

Caragliu, A., Del Bo, C., \& Nijkamp, P. (2009). Smart Cities in Europe. Serie Research Memoranda 0048 (VU University Amsterdam, Faculty of Economics, Business Administration and Econometrics).

Carter, P., Rojas, B., \& Sahni, M. (2011). Delivering Next-Generation Citizen Services; Assessing the Environmental, Social and Economic Impact of Intelligent $X$ on Future Cities and Communities, IDC White Paper, IDC Go-to-Market Services. Retrieved from: http://www.cisco.com/web/strategy/docs/scc/whitepaper_cisco_scc_idc.pdf

Chourabi, H., Nam, T., Walker, S., Gil-Garcia, J.R. Mellouli, S., Nahon, K., Pardo, T., \& Scholl, H. J. (2012). Understanding Smart Cities: An Integrative Framework. 45th International Conference on System Sciences. Hawaii.

Edvinsson, L. (2006). Aspects on the city as a knowledge tool. Journal of Knowledge Management, 10(5), 6-13. http://dx.doi.org/10.1108/13673270610691134

Eisenhardt, K.M. (1989). Building Theories from Case Study Research. The Academy of Management Review, 14(4), 532-550. http://dx.doi.org/10.5465/AMR.1989.4308385

Fletcher-Smith, F. (2014). DD1214 Smart London Innovation Network. http://www.london.gov.uk/mayor-assembly/gla/governing-organisation/executive-team/directors-decisions/DD121 4.

Florida, R. (2002). The Rise of the Creative Class. Basic Books.

Florida, R. (2005). The Flight of the Creative Class. HarperBusiness

Foray, D., Goddard, J., Goenaga, Beldarrain X. G., Landabaso, M., McCann, P., Morgan, K., Nauwelaers, C., \& Ortega-Argilés, R. (2012). Guide to Research and Innovation Strategies for Smart Specialisation (RIS 3). European Union. Retrieved from: http://s3platform.jrc.ec.europa.eu/ris3-guide

Glaeser, E. L., \& Berry, C. R. (2006). Why are smart places getting smarter?. Rappaport Institute for Greater Boston \& Taubman Centre, Policy Briefs. Retrieved from:

http://www.hks.harvard.edu/centers/rappaport/research-and-publications/policy-briefs/why-are-smart-places-gettin g-smarter

González J. A. A., \& Rossi, A. (2012). New Trends for Smart Cities. Open Innovation Mechanisms in Smart Cities Project, co-funded by the European Commission within the ICT Policy Support Programme. Retrieved from: http://www.opencities.net/node/119

Greater London Authority official website. (2013). Smart London vision. Retrieved from: https://www.london.gov.uk/priorities/business-economy/vision-and-strategy/smart-london.

Hollands, R. G. (2008). Will the real smart city please stand up? City, 12(3), 303-320. http://dx.doi.org/ $10.1080 / 13604810802479126$

Johnson, A. (2014). Stockholm; the Connected City. Retrieved from: http://www.stokab.se/Documents/Nyheter\%20bilagor/Stokab_eng.pdf.

Komninos, N. (2009). Intelligent cities: towards interactive and global innovation environments. International Journal 
of Innovation and Regional Development, 1(4), 337-355. http://dx.doi.org/10.1504/IJIRD.2009.022726

Komninos, N. (2011a). Intelligent cities: Variable geometries of spatial intelligence. Intelligent Buildings International, 3(3). http://dx.doi.org/172-188. 10.1080/17508975.2011.579339

Komninos, N. (2011b). What makes cities Smart? Smart Cities Conference, Edinburgh

Kourtit, K., \& Nijkamp, P. (2012). Smart cities in the innovation age. The European Journal of Social Science Research, 25(2), 93-95. http://dx.doi.org/10.1080/13511610.2012.660331

Kourtit, K., \& Nijkamp, P. (2013). Creative Buzz Districts in Smart Cities: Urban Retro-fitting and Urban Forward-fitting plans. Romanian Journal of Regional Science, 7(2), 37-57.

Landry, C. (2000). The Creative City: A Toolkit for Urban Innovators. Earthscan.

Lee, J. H., \& Gong, H. M. (2012). Toward a framework for Smart Cities: A Comparison of Seoul, San Francisco \& Amsterdam. Innovations for Smart Green City: What's Working, What's Not and What's Next, 26-27 June 2012. Stanford: Stanford Program on Regions of Innovation and Entrepreneurship.

Lombardi, P., Giordano, S., Farouh, H., \& Yousef, W. (2012). Modelling the smart city performance. The European Journal of Social Science Research, 25(2), 137-149. http://dx.doi.org/10.1080/13511610.2012.660325

Malthouse, K. (2014). The Mayor's Smart London Plan: making London an even better city to live in, using the creative power of new technologies to serve London and improve Londoners' lives. Smart City Event 2014, 13-14 May 2014. Amsterdam.

Miles, M., Huberman, M., \& Saldaña, J. (2013). Qualitative data analysis: A methods sourcebook. SAGE Publications

Nam, T., \& Pardo, T. (2011a). Smart City as Urban Innovation: Focusing on Management, Policy, and Context. 5th International Conference on Theory and Practice of Electronic Governance, Tallinn, Estonia, 185-194.

Nam, T., \& Pardo, T. (2011b). Conceptualizing Smart City with Dimensions of Technology, People, and Institutions. 12th Annual International Conference on Digital Government Research, College Park, MD, USA, 282-291.

Nikkei, B. P. (2010). Cleantech Institute. The Smart City Market Will Be Worth a Cumulative Total of 3,100 Trillion Yen for 2011-2030 - Nikkei BP Cleantech Estimates Based on Its Research on 100 Smart Cities Worldwide. Retrieved from: http://www.nikkeibp.com/news/100927.html.

Papa, R., Garguilo, C., \& Galderisi, A. (2013). Towards and urban planners' perspective on smart city. TeMA Journal of Land Use, Mobility and Environment, 6(1), 5-17. http://dx.doi.org/10.6092/1970-9870/1536

Ratti, C., \& Townsend, A. (2011). Harnessing Residents' Electronic Devices Will Yield Truly Smart Cities, Scientific Amrican. Retrieved from: http://www.scientificamerican.com/article.cfm?id=the-social-nexus.

Sauer, S. (2012). Do Smart Cities Produce Smart Entrepreneurs? Journal of Theoretical and Applied Electronic Commerce Research, 7(3). http://dx.doi.org/63-73. 10.4067/S0718-18762012000300007

Schaffers, H., Komninos, N., Pallot, M., Trousse, B., Nilsson, M., \& Oliveira, A. (2011). Smart Cities and the Future Internet: Towards Cooperation Frameworks for Open Innovation. In: Domingue Jea (ed) Lecture Notes in Computer Science, 431-446.

Shapiro, J. (2006). Smart Cities: Quality of Life, Productivity, and the Growth Effects of Human Capital. Review of Economics and Statistics, 88(2), 324-335. http://www.jstor.org/stable/40042998

Št’áhlavský, R. (2011). Amsterdam Smart City project. Retrieved from: http://www.top-expo.cz/domain/top-expo/files/tee/tee-2011/prednasky/prednasky\%202.\%20den/2-3\%20stahlavsky \%20roman\%20-\%20amsterdam\%20smart\%20city\%20project.pdf.

Stockholm Royal Seaport Innovation official website. (2014). Stockholm Royal Seaport Innovation. Retrieved from: http://www.stockholmroyalseaport.com/sv/

Stockholm smart city official website. (2014). The Smart City. Retrieved from: http://international.stockholm.se/city-development/the-smart-city/.

The Intelligent Community Forum. (2009). Stockholm, Sweden; Making "big" work better. Retrieved from: http://www.intelligentcommunity.org/index.php?src=news\&refno=304\&category=Community\&prid=304.

Tranos, E., \& Gertner, D. (2012). Smart networked cities? The European Journal of Social Science Research 25(2), 175-190. http://dx.doi.org/ 10.1080/13511610.2012.660327

Wolfram, M. (2012). Deconstructing Smart Cities: An Intertextual Reading of Concepts and Practices for Integrated Urban and ICT Development. REAL CORP 2012, 14-16 May 2012 Schwechat. 
Yin, R. (2003). Case Study Research: Design and Methods, London: SAGE Publications.

\section{(cc) EY}

This work is licensed under a Creative Commons Attribution 3.0 License. 